\title{
An Assessment of The Relationship Between Motivation And Teachers' Job Mobility In Ondo State, Nigeria
}

\author{
F. M. Osalusi Ph.D. \\ Department of Social Science Education, \\ Faculty of Education, Ekiti State University, Ado-Ekiti. \\ A. A. Onipede Ph.D. \\ Department of Social Science Education, \\ Faculty of Education, Ekiti State University, Ado-Ekiti.
}

\begin{abstract}
This paper investigated the relationship between motivation and teachers' job mobility in Ondo State, Nigeria. The study adopted a descriptive research of the survey type. The population consisted of all teachers of public secondary schools in Ondo State. Multistage sampling procedures were used to select the sample for the study. Stage one involved the use of simple random sampling technique to select 5 Local Government Areas from the 18 Local Government Areas in the State. The second stage involved the selection of 10 public secondary schools using purposive random sampling technique. 50 teachers were selected from each of the public schools using simple random sampling technique at third stage to make a total of 500 teachers as sample for the study. The content of the instrument was validated by relevant experts. The reliability was ascertained through test- retest method and Cronbach Alpha reliability coefficient method was used to determine the internal consistency of the items. The result yielded reliability coefficient of 0.87 . Data collected were analyzed using descriptive and inferential statistics. Frequency counts, mean scores, percentages were used to answer questions raised while Pearson's Product Moment Correlation and t-test were used to test the hypothesis at 0.05 level of significance. The study revealed that the level of teachers' job mobility was low and that motivational issues have a very high impact on teachers' job mobility. It was therefore recommended among others that Government at all levels and education stakeholders should encourage teachers to be committed to their jobs by providing necessary conducive environments and incentives to ensure better performance for national development.
\end{abstract}

Keywords: assessment, motivation, teachers, job mobility, better performance.

\section{INTRODUCTION}

Human resources appear to be very important in a nation or educational set up because human skills are important inputs and form the basis for better output. Human resources could be said to be an active agent of production which accumulates capital, explore other relevant resources, build and develop social, and economic institutions. The attainment of all these goals requires the provision of conducive climate to the satisfaction of the various needs of the teachers for dedication and effective performance of their jobs. Hence, countries must develop the skills and knowledge of their teachers and utilise them effectively.

Teachers appear to be one of the most important factors in the education system of a nation. Adelabu (2005) asserted that the work of a teacher goes beyond teaching, he/she builds up, instructs, trains and guides learners for healthy growth and stable adult life. However, it appears emphasis is not being placed on the importance of motivation which could make teachers put in their best. For a nation to develop, the teachers must be well taken care of 
because they are the springboard in school to enhance the development of a nation. It appears there is lack of satisfaction on the part of teachers to perform to their full capacity. For instance, Ushie \& Agba (2010) reported that in Nigeria, employees including teachers are continuously deprived of salaries, fringe benefits which have behavioral consequences on their efficiency. This phenomenon as opined by Bibi, Yasmin, Fozia \& Mola (2012) has threatened the effectiveness, growth and survival of most institutions in Nigeria. Government and proprietors of schools need to be aware that teachers have individual unique values, attitudes and sentiments that affect their performance to a large extent, and requires adequate care and provisions.

The issue of job mobility has become perennial in the public service in Ondo State and Nigeria in general as teachers and other professionals try to position themselves strategically in duty stations most appropriate to them. The situation of high staff turnover has been very much defined in the rural areas where untrained staff have continued to man the schools because highly qualified teachers prefer to teach in well developed areas. Lanzo (2000) was of the opinion that the loss of employees who have relatively high human capital value and choose to leave an institution can cause serious loss and difficulty, especially when the turnover numbers are on the rise. This in turn, seems to be capable of having negative impact on teachers motivation to perform productively.

Motivation is a complex socially learned pattern of behaviour, involving situations, needs, desires, mechanisms and results. Akinwumi (2000) was of opinion that, motivation is the process of influencing or stimulating a person to take action that will accomplish desired goals. It embraces all factors in an employee's development to accomplish personal as well as organisational goals. Motivation appears to determine whether an employee will do his/her work properly or not and also increases workers performance. For instance, issues of payment of salaries of workers, punishment or praises on performance are some motivational factors that need to be internalised in order to make workers effective. Internal incentives are ego needs of the employees which include job satisfaction, job accomplishment and prestige. Blum and Naylor (2004) noted that these are the spurning forces of achieving institutional objectives which also guides activities in the direction of getting goals. Monetary incentives entail rewarding workers for excellent job performance through better pay, fringe benefits, project bonuses, scheduled bonuses among others while non-monetary incentives include the rewards through opportunities such as flexible work hours, training, favourable work environment, among others.

Adelabu (2005) described a teacher as a person who teaches especially the young ones, builds up, instructs, trains and guides them for healthy growth and stable adult life. The teacher is also seen as someone who instructs others or provides activities, materials and guidance that facilitate learning in formal or informal situations. Ayeni (2005) believed that teacher's job goes beyond teaching but into molding young lives, guiding youth, motivating students and general character-training. The teacher can be viewed as one whose profession includes teaching, instructing, impacting knowledge and guiding learners to pass through the learning process. Therefore, motivation of teachers could be seen as a way of empowering them with the perceptions, variables, methods, strategies and activities used by the management for the purpose of providing a climate that is conducive to the satisfaction of the various needs of teachers so as to become satisfied, dedicated and effective in performing their task.

In contemporary work environment, Carvel (2000) was of the opinion that institution need to retain staff and ensure their effectiveness. This assertion was supported by Onyene (2001) when he said that teachers' motivation will boost their productivity, effectiveness, efficiency 
and dedication in performing their task and also enhance quality assurance, quality education and quality instructional delivery in the educational system. However, Gbadamosi (2002) noted that motivation is often under-utilised by most employers in the workplace. Becton, Wysocki \& Kepner (2009) stated that staff retention entails taking necessary measures to encourage workers to remain in their place of work for a reasonable period of time. It is currently observed that institutions are facing a lot of problems on workers mobility and effectiveness. As employing experienced staff is considered important for any institution, their retention and productivity is equally essential because there is no dearth of opportunities for a knowledgeable worker as a lot of institutions would be looking for him/her because no corporation can achieve its goal under frequent or unusual workers turnover.

In a study conducted by Ushie and Agba (2010), they noted that in Nigeria, rather than provide means by which workers could be motivated and retained for effective job performance, employers are seen to continuously deprived their workers physiological need through insecurity; delay in payment of salaries; and other fringe benefits that may have behavioral consequences on staff efficiency in the workplace. This situation as observed by Alao and Adelabu (2002) was said to be responsible for low morale among teachers as well as an adoption of supplementary livelihood that is capable of running down their institutions. All these according to Bibi; Yasmin; Fozia and Mola (2012) threatened the effectiveness, growth and survival of most institutions in Nigeria.

It was observed by this writer that as the number of public and private secondary schools increases in Ondo State, Nigeria, workers mobility and service inefficiency and ineffectiveness becomes higher. Fagbamiye (2000) noted that monetary and non-monetary incentives are critical in teacher mobility and job performance. Hudson and Sullivan (2000) remarked that emphasizing on one of the incentives at the expense of the other is risky to any institution. Monetary incentives are important as most teachers leave their jobs to another for better pay often refers to as greener pastures while others may stay because the institution satisfies their needs or their skills are fully utilised and are contributing to the achievement of the overall goal of the institution. Kei (2009) also observed that the workers are given chance to express their importance in the achievement of success in their piece of work. However, Ubom (2001) had earlier noted that if workers performance was base fundamentally on monetary, the private schools will lose their staff.

A survey of American Association of Retire Persons revealed that flexible schedules such as part-time hours and other non-monetary incentives are equally important in worker's productivity. For instance, there are high demand for teachers in the public and private schools in some specialised areas such as English language, Mathematics, Information Technology, Physics and others and since the supply is insufficient, the best bidder takes the day and when another high pay employer comes up, the former employers lose their teachers. Therefore, for any institution to survive under such environment, Ubom (2001) noted that aggressive recruitment and retention strategies are imperative to eliminate unwanted mobility. Blum Naylor (2004) was of the opinion that career development is a motivational incentive that promotes teachers' job performance. He went further to say that career management programmes and staffing programmes improved utilisation of workers overall institutional effectiveness and growth. The purpose of career development therefore is to match an employee's career aspirations with opportunities and challenges available within the 
institution. It also entails a successful placement of employees in positions that meet their needs as well as the institution needs. Similarly Ushie and Agba (2010) opined that too much time in one position may be perceived as career stagnation and have an adverse effect on teachers' commitment.

Euro stat (2010) stated that teachers that lacks opportunity have a number of adverse effects that could lead to low aspirations since they cannot realistically expect to advance very far hence, they trim their aspirations to suit the reality. It is pertinent that institutions adopt and legitimize the workers needs for career growth. Therefore, this study investigated the relationship between motivation and teachers job mobility in Ondo State, Nigeria.

The following research questions were raised:

\section{RESEARCH QUESTIONS}

1. What is the level of job mobility among secondary schools in Ondo State?

2. What is the impact of motivation on teachers' job mobility in Ondo State?

\section{RESEARCH HYPOTHESIS}

There is no significant relationship between motivation and teachers job mobility.

\section{RESEARCH METHOD}

The study adopted a descriptive research design of the survey type. The population consisted all teachers of public secondary schools in Ondo State. The Sample consisted of five hundred teachers selected through multi-stage sampling procedures. The first stage adopted a simple random sampling technique to select five out of the eighteen Local Government Areas in the State. Purposive random sampling technique was used to select ten public secondary schools from the Local Government Areas. Fifty teachers were randomly selected from each of the public schools.

A questionnaire tagged "Motivation and Teachers Job Mobility Questionnaire" (MTJMQ) was used to collect relevant data for the study. The validity of the items in the instrument was determined by expert in Social Studies Education and Test, Measurement and Evaluation. The reliability was determined by administering the items twice on twenty teachers in two secondary schools outside the sample schools. The data generated from the two tests were correlated using Alpha Cronbach reliability coefficient method which yielded a co-efficient of 0.87and this was considered good enough for this study. Descriptive statistics such as percentages, mean scores was used to answered the research questions while t-test and Pearson's Product Moment Correlation statistics were used to test the only hypothesis at 0.05 level of significance. 


\section{RESULTS}

\section{Question 1: What is the level of job mobility among secondary schools in Ondo State?}

Table 1: Descriptive analysis showing the level of job mobility among secondary schools in Ondo State

\begin{tabular}{|l|l|l|l|l|l|}
\hline & \multicolumn{2}{l|}{ Agree } & \multicolumn{2}{l|}{ Disagree } \\
\hline S/N & Item & $\mathbf{N}$ & $\mathbf{\%}$ & $\mathbf{N}$ & $\mathbf{\%}$ \\
\hline 1 & I have always be on transfer since I started teaching & 228 & 45 & 272 & 55 \\
\hline 2 & I have been transferred from rural to urban & 240 & 48 & 260 & 52 \\
\hline 3 & $\begin{array}{l}\text { I have experienced urban to rural transfer since I started } \\
\text { teaching }\end{array}$ & 180 & 36 & 320 & 64 \\
\hline 4 & Since I started teaching, I have not been transferred & 251 & 51 & 249 & 49 \\
\hline 5 & My transfer has been from urban to urban & 118 & 23.6 & 320 & 60.4 \\
\hline 6 & I have been transferred from rural to rural & 198 & 39.6 & 382 & 76.4 \\
\hline 7 & I have been resisting being transferred & 160 & 32 & 340 & 68 \\
\hline 8 & There has been irregular transfer of teachers & 320 & 64 & 180 & 36 \\
\hline 9 & Transfer of teachers has been adequately carried out & 176 & 35.2 & 304 & 64.8 \\
\hline 10 & $\begin{array}{l}\text { I am always satisfied with my transfer from one place to } \\
\text { another. }\end{array}$ & 178 & 35.6 & 322 & 64.4 \\
\hline & \multicolumn{1}{|c|}{ Mean } & $\mathbf{2 0 5}$ & $\mathbf{4 1}$ & $\mathbf{2 9 5}$ & $\mathbf{5 9}$ \\
\hline
\end{tabular}

This table revealed that $76.4 \%$ and $68 \%$ disagreed with item 6 and 7 respectively indicating that transfer of teachers were done frequently. Items 3, 5, and 10 recorded $64 \%, 60.4 \%$ and $64.4 \%$ disagreement respectively which is an indication that transfer of teachers have not been adequately carried out. On the average, $59 \%$ of the respondents disagreed with the level of job mobility among secondary school teachers in Ondo State. This implies that there are inadequacies in the level of job mobility among secondary school teachers in Ondo State, Nigeria as indicated in table 1.

\section{Question 2: What is the impact of motivation on teachers' job mobility in Ondo State?}

Table 2: Descriptive analysis showing the impact of motivation on teachers' job mobility in Ondo State

\begin{tabular}{|l|l|l|l|l|l|}
\hline & \multicolumn{2}{|l|}{ Agree } & \multicolumn{2}{l|}{ Disagree } \\
\hline S/N & Item & $\mathbf{N}$ & $\mathbf{\%}$ & $\mathbf{N}$ & $\mathbf{\%}$ \\
\hline 1 & $\begin{array}{l}\text { Lack of good welfare package will make me change to } \\
\text { another job }\end{array}$ & 382 & 76.4 & 118 & 23.6 \\
\hline 2 & $\begin{array}{l}\text { Good welfare and remuneration may enhance the teacher to } \\
\text { work well }\end{array}$ & 395 & 79 & 105 & 21 \\
\hline 3 & $\begin{array}{l}\text { I am not encouraged to teach effectively due to the school } \\
\text { condition of service }\end{array}$ & 320 & 64 & 180 & 36 \\
\hline 4 & Teacher should be given opportunity for fresh courses & 351 & 70.2 & 149 & 29.8 \\
\hline 5 & Adequate staff rooms are provided & 102 & 20.4 & 398 & 79.6 \\
\hline \multicolumn{1}{|c|}{ Mean } & $\mathbf{3 1 0}$ & $\mathbf{6 2}$ & $\mathbf{1 9 0}$ & $\mathbf{3 8}$ \\
\hline
\end{tabular}


The table shows 79\% indicating that lack of good welfare and remuneration may enhance the teacher to work, 76.4\% agreed that lack of good welfare package will make them change to another job. 70.2\% of the teachers agreed that teachers should be given opportunity for fresh courses while $64 \%$ agreed that they are not encouraged to teach effectively due to the school condition of service. Only $20.4 \%$ agreed that adequate staff rooms are provided for teachers. Results in the table revealed that on the average $62 \%$ of the respondents agreed which implies that motivation has an impact on teachers' job mobility in Ondo State.

\section{Hypothesis: There is no significant relationship between motivation and teachers job mobility.}

Table 3: t-test analysis of motivation and teachers' job mobility

\begin{tabular}{|l|c|c|c|c|c|}
\hline \multicolumn{1}{|c|}{ Variables } & $\boldsymbol{N}$ & Mean & $\boldsymbol{S D}$ & $\boldsymbol{r}_{\text {cal }}$ & $\boldsymbol{r}_{\text {table }}$ \\
\hline Motivation & 600 & 18.06 & 3.48 & \multirow{2}{*}{$.410^{*}$} & \multirow{2}{*}{0.195} \\
\hline Teachers' Job Mobility & 600 & 21.57 & 5.88 & & \\
\hline
\end{tabular}

${ }^{*} \mathbf{P}<0.05$

The table shows that $r_{\text {cal }}(0.410)$ is greater than $r_{\text {table }}(0.195)$ at 0.05 level of significance. This implies that there is significant relationship between motivation and teachers' job mobility.

\section{DISCUSSION}

The study revealed that the level of job mobility was inadequate among teachers in Ondo State, Nigeria. The study is in line with the findings of Oyowe (2001) who attributed teachers job mobility to unhealthy environment and lack in full professional expression. Poor communication among members of an institution may result into conflict and friction. Gerber (2004) therefore suggested that despite the fact that the movement of teachers occur without any change in skills level, responsibility allowance need to be paid for the psychological interests of transferring individuals to avoid conflict situations for the betterment of the institutions. The result of the study also revealed that teachers are not encouraged to teach in rural areas because of the condition of service in the areas. Gerber (2004) suggested that government and private sectors should work together to ensure adequate investment in areas which are shunned by professionals. Nwanko (2004) supported the remedy by noting that a hospitable environment should be developed especially in the rural areas to make them attractive to teachers.

The study revealed that motivation has a very high impact on teachers' job mobility in the state. This was supported by the findings of Hudson \& Sullivan (2000) with a report that emphasis on one of the incentives (monetary and non-monetary) at the expense of the other is risky to any institution. Monetary incentives are equally important because most teachers leave their job to another for better pay/greener pastures or stay because they just cannot find another job. Kei (2009) asserted that some teachers stay because their skills are fully utilised and are contributing to the achievement of the overall goal of the institution. And the workers are given chance to express their importance in the achievement of success in their place of work. The study further revealed that there is significant relationship between motivation and teachers job mobility. This is in line with the findings of Ushie \& Agba (2010) which reported that motivation influences and stimulates a person to take action that will accomplish desired goals. For example, pay, punishment or praise are external incentives or motivational factors that need to be internalised in order to make workers effective. Workers are not motivated and retained for effective job performance when they are continuously deprived of their 
physiological needs through delay in payment of salaries, insecurity, fringe benefits which may have behavioural consequences on their efficiency in their workplace. This phenomenon may therefore threatened the effectiveness, growth and survival of most institutions in Ondo State and in Nigeria in general.

\section{CONCLUSION}

The study concluded that motivation has a very high impact on teachers' job mobility and the level of teachers' job mobility was inadequate in Ondo State, Nigeria.

\section{RECOMMENDATIONS}

Based on the findings, it is therefore recommended that:

10. Efforts should be made by the government at all levels to ensure that teachers' welfare are adequately taken care of in the state.

11. Education stakeholders should encourage teachers with necessary incentives such as adequate payment of salaries, fringe benefits and other remunerations.

12. Adequate investment should be made in rural areas in terms of electricity and water supply and other amenities provision to ensure that teachers are encourage to stay there.

\section{References}

Adelabu, M. A. (2005). Teacher motivation and incentives in Nigeria. Retrived on October 2013 from www.dfid.gov.uk

Akinwumi, F.S. (2000). Impact of motivation and supervision on teacher productivity in secondary schools in Oyo State Nigeria. An Unpublished Ph.D thesis. University of Ibadan, Nigeria.

Alao, K. \& Adelabu. M. (2002). The challenges and problems of recruiting and retaining quality teachers for Nigerian schools. Paper presented at the $4^{\text {th }}$ World Assembly of International Council on Education for Teachers (ICET) Amsterdam.

Ayeni, A.J. (2005). The effect of principals' leadership styles on motivation of teachers for job performance in secondary schools in Akure South Local Government. Uunpublished M.A. Ed Thesis. Obafemi Awolowo University, Ile-Ife.

Becton, D, Wysocki G. \& Kepaer, IV (2009). How does a worker labour market history affect job duration. Melbourne Institute of Applied Economics and Social Research. The University of Melbourne.

Bibi, S; Yasmin, B; Fozia,B \&Mola,D. S.(2012). The nature and impact of teacher stress in the private schools of Gilgit-Baltistan, Pakistan. International Journal of academic research in progress education and development. 1(2), 64-84.

Blum, M.L. \& Naylor J.C (2004). .Industrial psychology: Its theoretical and social foundations. New Delhi: CBS Publishers \& Distributors.

Carvel, L. (2000). Teacher moral, job satisfaction and motivation. London: Paul Chapman Publishing 40(2),159172.

Eurostat (2010). Geographical and labour market mobility, special Euro barometer 337, wave 72.5, Eurostat, European Commission.

Fagbamiye, E.O. (2000). Teachers remuneration and condition of service; Job satisfaction. Ilorin: Nigeria Hayseed Publishers and Co.

Gbadamosi, L. (2002). Investigation into the attrition rate of Osun State Primary Basic Education in Nigeria. Ajayi et al (eds)National Institutes for educational planning and Administration (NIEPA) Nigeria.

Gerber, P.S. (2004). Human resources management (2nd ed) Halfway, House: Southern Book Publishers.

Hudson, R. \& Sullivan, T. (2000). Profession and professional, the Social organisation of work. East London Campus, East London 5201 South Africa. University of Fort Hare. 267-286. 
Kei, K. (2009). Residential Mobility and job change under uncertainty. Journal of Urban Economics. 54(3), 566-586.

Lanzo, A. (2000). Wages, no wage job characteristics and job mobility. Industrial and Labour Relations Review. 35(4), 190-102.

Nwankwo, J. N (2004). An introduction to economics, Ughelli: Eddy Joe Publisher.

Onyene, V. E. (2001). Issues in incentive administration for effective workforce retention: A study of some school teachers in Aquata. In N. Nwagwu, E. T. Ehiametalor, M. A. Ogunu \& M. Nwadiani (eds), Current issue in educational management in Nigeria. NAEAP. Benin: Ambik Press.

Oyowe, A. (2001). Brain drain colossal loss of investment for developing countries. Auburn University digital library. Retrieved from diglib.auburn.edu/.../library?...

Ubom, I. U. (2001). Value orientation, needs satisfaction and job performance of public servant in Akwa Ibom State. Ph.D. dissertation, University of Calabar, Calabar-Nigeria.

Ushie, E. M \& Agba, M. S. (2010). Supplementary livelihood strategies among workers in Nigeria: Implementation for organisation growth and effectiveness. International Journal of Business and Management 5(3),143-148. 